\title{
Reflections
}

\section{Geopolitical lives of children - commentary to Habashi}

\author{
SUNČANA LAKETA
}

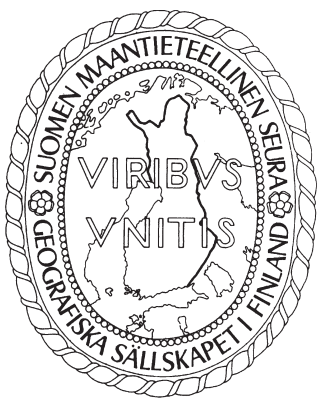

Laketa, S. (2019) Geopolitical lives of children - commentary to Habashi.
Fennia 197(1) 149-150. https://doi.org/10.11143/fennia.80159

I write this piece as a commentary to Habashi's article (this issue) on the national identity of Palestinian children. Habashi reminds us here that national identities are not static and fixed and that children need to be considered as active agents in constructing and reconstructing national and global politics. I take her long-standing commitment to Palestinian children's narratives of their own geopolitical worlds to consider the geopolitical lives of children in my own home country - Bosnia and Herzegovina.

Keywords: children, youth, geopolitics, national identity, school, Bosnia and Herzegovina

Sunčana Laketa, Institute of Geography, University of Neuchâtel, Espace LouisAgassiz 1, 2000 Neuchâtel, Switzerland. E-mail: suncana.laketa@unine.ch

As I write this commentary, I am reminded of an on-going struggle for democratic open and empowering education in the city of Jajce in Bosnia and Herzegovina $(\mathrm{BiH})$ where I grew up. Specifically, the children and youth of Jajce collectively stood up against the confines of nationally-driven education that perpetually pits one ethno-national group against the other. It all started in 2016 when the Ministry of Education announced the plan to establish a separate high-school for Bosniak (or Bosnian Muslim) students in the city. When students were notified of this decision, they organized a series of public protests against further efforts at segregation in this post-conflict city. It was one of the first public outcries against divided education organized by children and youth themselves, and it brought to public attention the importance of taking young people's voices seriously. In the words of Nikolas Rimac, one of the high-school students who organized the protest: "Unfortunately, they did not ask us anything, we suddenly found out about the division last year. They said it was an issue for the parents... of course, we should be consulted because you cannot have a school without pupils, can you" (Bešlija 2017).

Rimac and his peers took active ownership of their education in ways that challenged their assumed passivity in the field most heavily targeted by antagonistic nation-building processes. Children are often instrumentalized in various nation-building projects, as Habashi's (2019) work testifies. Nationbuilding takes different shapes and forms through which a sense of belonging to a national community is formed. Children learn to become Bosnian, Palestinian or Swiss through informal interactions in families, communities and localized places. But they also find themselves as targets of nation-building through more formal institutions, primarily the schools. In $\mathrm{BiH}$, education is completely divided among the three ruling ethno-national groups, a situation that was created during the war of 1992-1995 and that continues to this day. Reflecting the system of segregated education, the new school in Jajce was an effort to construct a so-called "two schools under one roof" model, an educational monstrosity that segregates children, teachers, textbooks and school administration on an ethno-national basis. It is part of a continuous effort by political elites to maintain ethnically "clean" spaces of education where

URN:NBN:fi:tsv-oa80159

DOI: 10.11143/fennia.80159 a Creative Commons Attribution 4.0 International License. 
"apples and pears don't mix", to paraphrase the infamous statement of Greta Kuna, the former education minister in $\mathrm{BiH}$. The self-other construction that Habashi explores in her work becomes an institutionalized binary in the spaces of the "two schools under one roof".

However, "you cannot have schools without pupils", as Rimac powerfully remarks. Joined and supported by some of their teachers, the children and youth staged collective walk-outs, marches and protests, slowly gaining publicity from national and international media. It was a year-long struggle that ended with a victory: the Ministry of Education finally abandoned the plan for the separate school. The event represents a step on a long-path to construct a socially just society, but an important step as well as the effects continue to resonate among other communities and schools in $\mathrm{BiH}$. Similar to their peers in Palestine, the children of Jajce are not simply victims of the precarious post-conflict environment that they inherited but are rather actively constructing their geopolitical worlds. Even more, the events in Jajce testify to the political power of youth to contest dominant narratives.

Finally, as I use Habashi's (2019) article as a sounding board for some of the complexities of children's national identities in $\mathrm{BiH}$, I would like to end with a few words on the open-review process for this article. It was an enlightening process that I was happy to be a part of. I found it to be an open form of dialogue that is filled with challenging, yet productive interactions. Without the comfort of anonymity, the peer-review becomes a much more ethical and responsible endeavour. The process enables us to discuss each other's work with grace and respect even in the moments of disagreement and friction. I would like to thank Janette Habashi, Sandy Marshall and Kirsi Kallio for doing peerreview differently together.

\section{References}

Bešlija, A. (2017) Nikolas Rimac: We are not afraid of revenge, our teachers are with us! Interview.ba 28.3.2017 <https://interview.ba/interview/item/137-b-nikolas-rimac-b-we-are-not-afraid-of-revengeour-teachers-are-with-us>

Habashi, J. (2019) Palestinian children: a transformation of national identity in the Abbas era. Fennia 197(1) 77-93. https://doi.org/10.11143/fennia.71009 